Iwona H. Pugacewicz

Warszawa

\title{
Polonistyka w Lille \\ Kilka refleksji na marginesie międzynarodowej konferencji zorganizowanej w ramach obchodów 80-lecia polonistyki na Uniwersytecie Charles-de-Gaulle Lille III
}

W dniach 6-7 grudnia 2007 r. na Uniwersytecie Charles-de-Gaulle Lille III mającym swoją siedzibę $\mathrm{w}$ jednym $z$ elegantszych przedmieść Lille, $w$ VilleNeuve-d'Ascq, obchodzono uroczyście 80-lecie powstania sekcji polskiej - Etudes de Langue, Littérature et Civilisation polonaises, posadowionej jako niezależna katedra w ramach UFR d'Etudes Romanes, Slaves et Orientales.

Zainteresowania polską kulturą, a zwłaszcza naszą historią i literaturą, we Francji mają świetny rodowód i sięgają czasów Wielkiej Emigracji. Wówczas to do Collège de France w Paryżu na wykłady Adama Mickiewicza wygłaszane w Katedrze Literatury i Języków Słowiańskich (lata 1840-1844) uczęszczało nie tylko polistopadowe, elitarne wychodźstwo wojskowe, ale przede wszystkim międzynarodowa elita intelektualistów zainteresowana kulturą i dziejami nieistniejącego państwa.

Po odzyskaniu przez Polskę niepodległości Katedra Literatur Słowiańskich w Collège de France straciła na popularności. Stąd też nowe projekty rozwoju polskich studiów, nieco inaczej uplasowanych na geopolitycznej mapie naukowych instytucji Francji. Najpierw rozważano powołanie stosownej komórki, specjalizującej się w badaniach nad językiem i kulturą polską na Sorbonie. Niestety, $z$ uwagi na zbyt wysokie koszty (francuska pensja profesora uniwersyteckiego wynosiła wówczas pomiędzy 60000 - 90000 franków rocznie) oraz problemy natury kadrowo-administracyjnej, projekt ów odroczono w czasie. Sytuacja była tym bardziej skomplikowana, że „cechą sfer uniwersyteckich francuskich wychowanych w atmosferze przymierza rosyjsko-francuskiego", jak donosił w swym liście do ówczesnego Ministra Spraw Zagranicznych Rzeczpospolitej Polskiej prof. Zygmunt Zaleski, była ogólna obojętność wobec Polski po zakończeniu I wojny światowej. Zresztą prof. Zaleski napotkał na swej drodze analogiczne problemy, jeśli idzie o utworzenie sekcji polskiej w Instytucie Studiów Słowiańskich w Paryżu. Po powstaniu niniejszej sekcji wykłady z literatury polskiej miały jedynie charakter wolnych kursów nie obwarowanych żadnymi egzaminami, co w praktyce umniejszało ich znaczenie. Sygnalizując pokrótce wybrane zagadnienia i problemy dotyczące starań w upowszechnia- 
niu polskiego języka i kultury w ramach przedsięwzięć naukowo-dydaktycznych podejmowanych w Paryżu w okresie międzywojnia, warto również wspomnieć o kursach języka polskiego zwanych wolnymi kursami organizowanych w Szkole Języków Wschodnich (Ecole Nationale des Langues Orientales ), analogicznych zajęciach organizowanych w Szkole Wojskowej (Ecole Militaire) oraz w Stowarzyszeniu Propagowania Języków Obcych (Société pour la Propagation des Langues Etrangères). Niestety, żadne $z$ nich nie miały charakteru regularnych studiów sankcjonowanych chociażby na poziomie licencjatu. Tak, więc w nowej rzeczywistości pamięć o polskim, intelektualnym Paryżu Wielkiej Emigracji powoli stawała się swego rodzaju historycznym symbolem, a marzenia o pełnoprawnej polskiej katedrze uniwersyteckiej emigrowały na francuską prowincję, gdzie padały na zdecydowanie bardziej podatny grunt.

Spośród szesnastu okręgów uniwersyteckich najbardziej interesujący i przyjazny owej idei okazał się ośrodek w Lille. Założenie polonistyki na tutejszym, państwowym uniwersytecie nie było dziełem przypadku. Nie do przecenienia okazała się być argumentacja prospołeczna, ściśle związana $z$ historią polskiej emigracji zarobkowej, masowo napływającej w okresie międzywojnia do departamentów Nord i Pas de Calais. Według oficjalnych szacunków, w 1926 r. społeczność polonijna północnej Francji to 140577 nowoprzybyłych. Przed drugą wojną światową całość polskiej emigracji na tamtych terenach szacowano na około 500 000. Stąd też konieczność tworzenia stosownej infrastruktury oświatowej, w tym związanej ze szkolnictwem wyższym. Obecność w dwóch północnych departamentach tak licznej, wewnętrznie różnorodnej (część reemigrowała z Westfalii, część bezpośrednio z ziem polskich, jako pracownicy kontraktowi, sezonowi etc.) i dynamicznie rozwijającej się polskiej grupy narodowościowej została zauważona nie tylko przez administrację regionalną, ale zwróciła tė̇ uwage $\operatorname{wład} z$ kościelnych, świadomych duchowych potrzeb owej przybyłej ze wschodu społeczności. Kościołowi francuskiemu zależało na przygotowaniu przyszłych księży do pracy wśród polskiej emigracji. I tak przy udziale finansowego wsparcia ze strony władz kopalnianych (30 000 franków), w listopadzie 1926 r., wyprzedzając równoległe starania władz świeckich, na Uniwersytecie Katolickim w Lille zainaugurowano nauczanie języka polskiego. Wprawdzie nadal nie były to pełnoprawne studia uniwersyteckie sankcjonowane stosownym dyplomem, niemniej ich uruchomienie ukazało powagę i zaangażowanie strony francuskiej jak i determinację polonijnej społeczności.

Marzenia o „państwowej, francuskiej polonistyce” spełniły się w rok później. Dzięki zabiegom francuskich profesorów z Uniwersytetu Państwowego w Lille decyzją ministra Eduarda Herriota powołano w 1927 r. Katedrę Języka Polskiego na Uniwersytecie Państwowym w Lille. Od początków jej istnienia, zważywszy na genezę i szczególnie interesujące okoliczności tworzenia, wiązano $z$ nią duże nadzieje. Jej pierwszym profesorem - kierownikiem został Antoine Martel, autor znanej dysertacji poświęconej językowi polskiemu na Rusi w XVII w. Powstanie nowego kierunku poparły swym autorytetem i stosowną reklamą między innymi takie sławy jak Georges Lefèvre - wówczas dziekan 
Wydziału Humanistycznego na Uniwersytecie w Lille i wyżej wspomniany prof. Zygmunt Lubicz-Zaleski - profesor literatury, poeta i dyplomata polski we Francji w okresie międzywojennym.

Od tego czasu w ciągu osiemdziesięciu lat przez katedrę przewinęły się dziesiątki studentów zarówno polskiego jak i francuskiego pochodzenia, wiele znakomitości ze świata nauki i kultury. Wydano pokaźną ilość publikacji poświęconych w przeważającej części językowi i kulturze polskiej emigracji północnej Francji, poświadczających prowadzone tam przez lata badania, zorganizowano wiele spotkań, odczytów i konferencji, stworzono stosowne zaplecze naukowodydaktyczne $z$ biblioteką liczącą dziś ponad 20 tys. woluminów.

Tegoroczny jubileusz - osiemdziesięciolecia istnienia, zorganizowany przez szanowną jubilatkę - Katedrę Polonistyki, Centre d'Etudes en Civilisation, Langues et Lettres Etrangères wspólnie z Konsulatem Polskim w Lille, Stowarzyszeniem Studentów Polskich we Francji, tutejszą biblioteką centralną i tzw. Action Cultur na Uniwersytecie Lille III stanowił świetną okazję do wspomnień i podsumowań. $\mathrm{W}$ programie obok prezentacji wydawanych przez lata na uniwersytecie publikacji, obok wystawy dokumentów dotyczących powstania sekcji, prezentacji obrazów podarowanych polonistyce, na czele $z$ jednym $z$ najlepszych płócien Jana Wacława Zawadowskiego, najbliższego przyjaciela Modiglianiego, przewidziano występ aktorów $\mathrm{z}$ francuskiego teatru Passerelles przedstawiających wspomnienia i refleksje $z$ getta warszawskiego $\mathrm{w}$ oparciu o oryginalne teksty i materiały źródłowe $z$ archiwum Emanuela Ringelbluma. O Archiwum Ringelbluma, jednym $z$ najcenniejszych źródeł wiedzy na temat funkcjonowania getta, w skład którego wchodzi zespół dokumentów liczących 1680 jednostek archiwalnych, jest w tym roku szczególnie głośno we Francji, a to za sprawą ukazania się po raz pierwszy na tutejszym rynku wydawniczym jego dwóch pierwszych tomów. W pracach translatorskich nad tomem drugim zatytułowanym Les enfants et l'enseignement clandestin dans le getto de Varsovie, wydawnictwo Fayard 2007, wzięła udział jedna $z$ czołowych osobowości naukowych pracujących na polonistyce w Lille III - prof. Maryla Laureat. Stąd też wybór takiego rodzaju spektaklu i tłumaczenia.

Niewątpliwie najważniejszym elementem obchodów urodzin polonistyki była konferencja naukowa poświęcona tematyce emigracyjnej pod znamiennym tytułem Wyjeżdżać, emigrować, uciekać... (Partir, émigrer, s'exiler: ou comment l'histoire, la littérature ou la linguistique abordent le gests de départ, la rencontre de l'autre et ses conséquences).

Organizatorom udało się w sposób niezwykle zrównoważony zaprezentować trzy najważniejsze wątki tematyczne wynikające $z$ treści referatów:

1) wątek wspomnieniowo-refleksyjny,

2) naukowo-badawczy odnoszący się do języka, historii i socjologii emigracji współczesnej, powojennej jak i okresu międzywojnia,

3) dydaktyczno-analityczny przedstawiający dokonania oraz zaniedbania na polu oświaty polonijnej, próbujący zaimplantować analizę i retrospekcję socjo- 
historyczną do celów dydaktyki przyszłości.

Uroczystego otwarcia obrad dokonał jeden $z$ głównych organizatorów obchodów prof. Marek Tomaszewski, kierownik sekcji polskiej od 1998 r. Za jego szefowania rozpoczęto między innymi studia korespondencyjne, uruchomiono egzaminy certyfikacyjne j. polskiego jako obcego. Do grona jego najbliższych pracowników, inicjujących wszelkie akcje o charakterze naukowym, mające na celu promocje kultury i literatury, należą zarówno uznani w środowisku naukowcy: Brigitte Gautier, Maryla Laureat, jak i dobrze zapowiadający się doktoranci Dagmara Gut, Eremy Lambert, i Agata Śluzar-Dobrowolska. Ekipa ta kształci obecnie około stu studentów $z$ całej Francji, w większości polskiego pochodzenia.

Niewątpliwie najważniejszymi uczestnikami konferencji byli trzej wielcy poprzednicy profesora Tomaszewskiego, których naukowe życiorysy i dorobek bibliograficzny świadczą o znakomitej historii omawianej instytucji:

- prof. Edmond Marek pełniący funkcje kierownika katedry w latach 19721979, wychowanek Sekcji Polskiej w Lille, romanista, filolog klasyczny, polonista, założyciel Ośrodka Studiów i Badań nad Społecznością Polsko-Francuska w 1978, inicjator wymiany i współpracy ze Studium Kultury Współczesnej Uniwersytetu Wrocławskiego, autor między innymi pierwszej, krótkiej historii Katedry Polonistyki na Uniwersytecie Lille III wydanej w roku 1992, z okazji 65lecia jej istnienia, żarliwy propagator scalenia, gromadzenia i katalogowania rozproszonych dokumentów i pamiątek będących świadectwem minionych czasów polonijnej społeczności północnej Francji;

- prof. Daniel Beavuois, francuski historyk uznany w środowisku międzynarodowym, rusycysta i polonista, badacz pogranicza kultur: polskiej, ukraińskiej i rosyjskiej, kierownik katedry polonistyki na uniwersytecie w Lille w latach 1979-1995, szefujący równiė̇ Ośrodkowi Historii Słowian na Sorbonie, członek PAN, PAU oraz Ukraińskiej Akademii Nauk, orędownik demokratycznych zmian mających miejsce w Polsce w latach osiemdziesiątych, wielce zasłużony dla polskiej Solidarności we Francji;

- prof. Edmond Gogolewski, pierwszy, wywodzący się bezpośrednio ze środowiska górniczego polskiej emigracji, który podjął wyższe studia polonistyczne zostając do końca wiernym ośrodkowi w Lille, gdzie w latach 1995-1998 sprawował funkcję kierowniczą; jako jeden $z$ nielicznych zajął się opisaniem dziejów polskich górników w północnej Francji, szkicował koleje losów polskiego i polonijnego szkolnictwa elementarnego i średniego w regionie NordPas-de-Calais oraz opisywał życie stowarzyszeniowe Polonii w okresie międzyi powojennym; dzisiaj nadal jest oddanym orędownikiem na rzecz polskiej emigracji, członkiem zwyczajnym Światowej Rady Badań nad Polonią, szczególnie wspierającym miejscowe (północnofrancuskie) stowarzyszenia polonijne.

Jeśli idzie o profesorów, doktorów, asystentów przybywających na uniwersytet $z$ gościnnymi lub czasowymi wykładami, prowadzących badania własne, wspierających tutejszą dydaktykę - przewinęły się ich dziesiątki. Na szczególną uwagę zasługuje postać Pani prof. Zofii Cygal-Krupy z Uniwersytetu Jagielloń- 
skiego - przez 13 lat związanej z lilską katedrą, skrzętnie dbającej o jej zewnętrzny obraz, kultywującej nie tylko polską naukę, ale i tradycyjne zwyczaje. Uczestnicy konferencji $z$ rozrzewnieniem, w rozmowach kuluarowych, wspominali organizowane przez nią wigilie i inne typowo polskie wieczorki. Jej referat odnoszący się do badań nad językiem polskiej emigracji, zachodzącymi w nim zmianami w okresie międzywojnia dotyczył w pewnym sensie zapomnianego życia codziennego emigracji.

Nauczaniu języka polskiego, historii i kultury polskiej w ujęciu zarówno historycznym jak i odnoszacym się do przyszłości poświęcone były dwa kolejne wystąpienia: niezmiernie interesujące - żarliwego polonofila, Gabriela Garçon, profesora matematyki z Wyższej Szkoły Inżynieryjnej z Lille, analizującego uniwersyteckie koleje nauczania, ze szczególnym uwzględnieniem roli wspomnianego wyżej Uniwersytetu Katolickiego oraz autorki niniejszego tekstu poświęconego polskiemu szkolnictwu we Francji i jego perspektywom.

Niezwykle interesujące i atrakcyjne naukowo okazały się referaty badaczy prezentujących środowisko wrocławskie, wyjątkowo zasłużone dla polonistyki w Lille. W zasadzie wszyscy prelegenci $z$ Uniwersytetu Wrocławskiego przybyli na konferencję w przeszłości wykładali na Uniwersytecie Lille III, część $z$ nich wydała tam swoje najważniejsze prace, pierwsze tłumaczenia. Popołudnie wrocławskie rozpoczął prof. Władysław Dynak niezwykle refleksyjnym tekstem zatytułowanym Zostać w raju czy wracać do piekła? Ze wspomnień byłego wykładowcy języka i literatury polskiej w Sekcji Polskiej w latach 1980-1982. Motyw emigracji, bardziej w ujęciu językowym towarzyszył kolejnym dwóm wystapieniom: prof. Elżbiety Skibińskiej, Językowy obraz wygnańca oraz prof. Kazimierza Ożoga z Lublina: Emigrować z ojczyzny, emigrować z języka.

Ostatnie, późno popołudniowe trzy wystapienia: prof. Stanisława Beresia i dr Małgorzaty Misiak $z$ Uniwersytetu Wrocławskiego oraz prof. Anny Pilch z ośrodka krakowskiego, dotyczyły badań własnych nad zagadnieniami związanymi $z$ literaturą i socjologią ucieczki, bycia, przeżycia i tworzenia na emigracji.

Konferencja stanowiła nie tylko ważne wydarzenie w życiu Uniwersytetu Charles-de-Gaulle Lille III, ale spotkała się z szerokim zainteresowaniem zarówno francuskiej polonii, licznie reprezentowanej w trakcie obrad, jak i władz polskich. Wśród uczestników nie zabrakło przedstawicieli zaprzyjaźnionych francuskich i międzynarodowych ośrodków naukowo-kulturalnych. Wśród gości Z polskich placówek warto ponadto wymienić radcę do spraw naukowych przy Ambasadzie Polskiej w Paryżu, Elżbietę Sayegh oraz radcę Joannę Karasek z Ministerstwa Spraw Zagranicznych. Konferencji towarzyszyły niezwykle interesujące dyskusje dotyczące zarówno treści zawartych w poszczególnych wystapieniach jak i obrazujące bardziej praktyczne i codzienne problemy nauki polskiej na emigracji. Wskazano pola badawcze warte zagospodarowania, zaprezentowano najnowsze źródła do badań nad językiem i życiem codziennym emigracji. Dyskutowano jej dalszy rozwój, zmiany, jakie mogą nastąpić w jej funkcjonowaniu po otwarciu w 2009 r. granicy ekonomicznej między Francja 
a Polską. Formułowano wreszcie oczekiwania odnośnie polskiej nauki i nauczania poza granicami wobec władz polskich.

Próbując podsumować owo bezprecedensowe polonijne wydarzenie, powróćmy raz jeszcze do przykładów tym razem $z$ niedalekiej przeszłości oraz współczesnych potrzeb naukowo-badawczych. Według szacunków przeprowadzonych w 1974 r. na wszystkich wyższych uczelniach w Lille, na ogólną liczbę około 20 000, studiowało 1840 studentów polskiego pochodzenia (o czysto polskich nazwiskach). $Z$ tego zaledwie $1 / 10$ uczęszczała na różnorodne wykłady lub lektoraty $z$ literatury i języka polskiego. Na przestrzeni ponad trzydziestu lat wiele się zapewne zmieniło. Nie znamy, niestety aktualnych kierunków i tendencji, nie za bardzo wiemy jak dzisiaj przedstawia się osobowość kulturalna Polaków na uczelniach północnej Francji, jak są przekazywane i przyjmowane polskie i polonijne wartości naukowo-kulturalne przez kolejne pokolenia emigrantów, jakie zmiany im towarzyszą, etc. Miejmy nadzieję, że chociaż część z wyżej proponowanych zagadnień zostanie podjęta w ramach przyszłych prac naukowych jako wniosek, postulat badawczy wynikający $z$ tegorocznej konferencji.

Warto też na nowo, w sposób zaplanowany i zorganizowany, podjąć jakże istotne wyzwanie prof. E. Marka $z$ lat 70-tych minionego stulecia dotyczące powołania do życia Archiwum Polonii Północnej Francji. Jego stworzenie nie tylko uchroniłoby emigracyjną spuściznę literacką, pamiątki i dokumenty przed zapomnieniem i zniszczeniem, ale stanowiłoby bazę do podejmowania dalszych prac i badań naukowych nad polskim wychodźstwem. Prace zmierzające do uruchomienia pierwszej Biblioteki Polonijnej Północnej Francji, a w przyszłości jej archiwum, zostały w minionym roku podjęte przez organizacje polonijne skupione w Maison de la Polonia, Centrum Informacji i Dokumentacji o Polonii Francuskiej, we współpracy ze Stowarzyszeniem „Wspólnota Polska”, Konsulatem Generalnym RP w Lille oraz Instytutem Informacji Naukowej i Studiów Bibliologicznych Uniwersytetu Warszawskiego. Byłoby niezwykle pożądane, ażeby w przyszłości do tej akcji przyłączyły się miejscowe środowiska akademickie na czele $z$ Katedrą Polonistyki $z$ szacownego Lille III.

Skoro dotknięto tematyki związanej z dokumentem i książką emigracyjną, warto podzielić się jeszcze jedną refleksją. Szkoda, że na konferencji nie zostało bliżej zaprezentowane owo najważniejsze zaplecze pracy naukowo-dydaktycznej, jakim jest biblioteka studiów slawistycznych, w ramach której zgromadzono ponad 20-tysięczne zbiory tutejszej polonistyki. Zważywszy na duże zainteresowanie, jakie wywarła prezentacja prac powstałych i wydanych na polonistyce, tym bardziej pożądane byłoby pełniejsze zaprezentowanie owej polonijnej książnicy. Zapewne stosowna promocja jej zbiorów, wśród których na znaczną uwagę zasługują chociażby te przekazane przez prof. Wacława Godlewskiego, szefa polonistyki w latach 1945-1972, przyczyniłaby się do szerszego zainteresowania badaniami nad historią, kulturą i literaturą emigracyjną.

Symboliczne zakończenie jubileuszowych obchodów odbyło się w najbardziej polskiej ze wszystkich polskich i polonijnych placówek - Konsulacie Generalnym w Lille. Po niezwykle owocnym, a zarazem pracowitym dniu wszyscy 
prelegenci, goście, osobistości ze świata nauki i polityki na czele $z$ przedstawicielami władz regionalnych północnej Francji zostali zaproszeni tam przez Panią Konsul Wandę Krystynę Kalińską na polski koktajl. Pani Konsul, podsumowując 80 lat istnienia polonistyki na Uniwersytecie Lille III, odnosząc się również do całości polskiej nauki i kultury promowanej w regionie, wymieniła najbardziej zasłużone $\mathrm{w}$ tej mierze osobistości, podziękowała wszystkim za dotychczasową pracę życząc jednocześnie pomyślności, sił i zapału na dalsze dziesięciolecia.

Efektem finalnym konferencji będzie publikacja naukowa, która miejmy nadzieję przyczyni się do rzeczowej dyskusji w kraju na temat kierunków rozwoju, kondycji polskich instytucji kultury, nauki i nauczania poza granicami Polski. 